\title{
Adiponectin Expression in the Porcine Ovary during the Oestrous Cycle and Its Effect on Ovarian Steroidogenesis
}

\author{
Anna Maleszka, Nina Smolinska, Anna Nitkiewicz, Marta Kiezun, Katarzyna Chojnowska, \\ Kamil Dobrzyn, Hubert Szwaczek, and Tadeusz Kaminski
}

Department of Animal Physiology, University of Warmia and Mazury in Olsztyn, Ulica Oczapowskiego 1A, Kortowo, 10-719 Olsztyn, Poland

Correspondence should be addressed to Tadeusz Kaminski; tkam@uwm.edu.pl

Received 28 November 2013; Accepted 19 February 2014; Published 26 March 2014

Academic Editor: Anna Ptak

Copyright (C) 2014 Anna Maleszka et al. This is an open access article distributed under the Creative Commons Attribution License, which permits unrestricted use, distribution, and reproduction in any medium, provided the original work is properly cited.

\begin{abstract}
Adiponectin is an adipose-secreted hormone that regulates energy homeostasis and is also involved in the control of the reproductive system. The goal of the present study was to investigate changes in adiponectin gene and protein expression in porcine ovarian structures during the oestrous cycle and to examine the effects of in vitro administration of adiponectin on basal and gonadotrophin- and/or insulin-induced secretion of ovarian steroid hormones. Both gene and protein expression of adiponectin were enhanced during the luteal phase of the cycle. Adiponectin affected basal secretion of progesterone by luteal cells, oestradiol by granulosa cells, and testosterone by theca interna cells. The gonadotrophin/insulin-induced release of progesterone from granulosa and theca interna cells and the release of oestradiol and androstenedione from theca cells was also modified by adiponectin. In conclusion, the presence of adiponectin mRNA and protein in the porcine ovary coupled with our previous results indicating adiponectin receptors expression suggest that adiponectin may locally affect ovarian functions. The changes in adiponectin expression throughout the oestrous cycle seem to be dependent on the hormonal status of pigs related to the stage of the oestrous cycle. The effect of adiponectin on ovarian steroidogenesis suggests that this adipokine influences reproductive functions in pigs.
\end{abstract}

\section{Introduction}

The adipose tissue is an endocrine organ that produces various factors including the adipokines [1]. One of them, adiponectin, also known as Acrp30, AdipoQ, GBP28, and apM1, was discovered by four independent research teams in 1995/1996, [2-5] as the most abundant product of the adipose tissue [6]. The hormone is a 244 -amino acid protein with $30 \mathrm{kDA}$ molecular weight that circulates in the serum in different multimeric forms [5]. Actions of adiponectin are mediated by two types of receptors: adiponectin receptor 1 (AdipoR1) and 2 (AdipoR2). The receptors are highly related and share $67 \%$ sequence identity in mice, but they differ in their tissue distribution and the ability to bind various forms of adiponectin. AdipoR1 shows high affinity for the globular form of adiponectin, whereas AdipoR2 is characterized by intermediate binding affinity for both globular and fulllength adiponectin [7]. The highest levels of AdipoR1 expression are observed in skeletal muscles, whereas AdipoR2 is most highly expressed in the liver $[7,8]$. Due to the extensive distribution of adiponectin receptors in peripheral tissues and organs, adiponectin exerts pleiotropic effects on metabolism, including regulation of homeostasis by fatty acid oxidation, stimulation of glucose uptake and gluconeogenesis inhibition, which leads to intensified thermogenesis and weight loss [9]. Consequently, adiponectin level correlates negatively with body fat [10] and positively with insulin sensitivity [11].

The existing evidence points to the presence of a common endocrine system comprising several hormones, including ghrelin, leptin, and orexin that controls metabolism and reproductive functions [12-15]. It is believed that adiponectin 
belongs to the above group of hormones. Adiponectin mRNA and protein were found in the ovaries of several species, including humans, rats, and cows [16-19]. Adiponectin mRNA and protein were also detected in the ovaries of prepubertal but not sexually mature gilts [8]. The influence of the hormonal status of swine related to the stage of the oestrous cycle on adiponectin expression in corpora lutea, granulosa, and theca interna cells remains unknown. Studies indicating higher concentrations of adiponectin in female than in male blood suggest that ovarian steroids may regulate adiponectin secretion $[20,21]$. Similar conclusions can be drawn from varied plasma levels of adiponectin during the oestrous cycle in pigs [22]. Despite the above, the possible influence of adiponectin on the production of steroid hormones by porcine ovarian cells remains unexplored. Therefore, the aim of this study was to investigate the expression of the adiponectin gene by real-time PCR, to determine the concentrations of adiponectin protein in the porcine ovary (corpora lutea, granulosa and theca interna cells) and to compare gene and protein expression levels during different stages of the oestrous cycle in pigs. Additionally, we sought to determine the in vitro effect of adiponectin on the secretion of steroid hormones (progesterone, oestradiol, testosterone, and androstenedione) by ovarian luteal, granulosa, and theca interna cells of sexually mature swine.

\section{Materials and Methods}

2.1. Experimental Animals. All experiments were carried out in observance of the ethical standards of the Animal Ethics Committee at the University of Warmia and Mazury in Olsztyn. The experimental material comprised mature gilts (Large White and Polish Landrace) from a private breeding farm, aged 7-8 months and weighing 130-140 kg. Twenty gilts were divided into four experimental groups as follows: days $2-3,10-12,14-16$, and 17-19 of the oestrous cycle. Females were monitored daily for oestrus behaviour in the presence of an intact boar. The day of the second oestrus was designated as day 0 of the oestrous cycle. The phase of the oestrous cycle was also determined based on ovarian morphology [23]. Additionally, to fully confirm correctness of the evaluation of the oestrous cycle phase, the level of progesterone was determined [24]. The ovaries were removed and placed on ice within minutes after slaughter. Dissected corpora lutea (CLs) from different stages of the oestrous cycle (days 2-3-corpora haemorrhagica, 10-12-mature CLs, and 1416-regressing CLs) were either immediately frozen in liquid nitrogen and stored at $-80^{\circ} \mathrm{C}$ until RNA and protein analysis or, similarly to the ovaries from days 17-19 of the cycle, placed in cold PBS buffer and transported to the laboratory where luteal, follicular granulosa, and theca interna cells were isolated. Granulosa and theca interna cells are precursor cells of large and small luteal cells, respectively.

2.2. Isolation of Luteal, Granulosa, and Theca Interna Cells. Luteal cells were isolated by the method described by Kaminski et al. [25]. Dissected corpora lutea from ovaries on days $2-3,10-12$, and $14-16$ were minced into small fragments and dispersed in F-12 medium containing bovine serum albumin fraction $\mathrm{V}$ (BSA; 1\%) and antibiotics. Corpora lutea were enzymatically dissociated in $0.125 \%$ trypsin solution (4-6 times) at $37^{\circ} \mathrm{C}$, centrifuged $\left(300 \times \mathrm{g}, 10 \mathrm{~min}, 4^{\circ} \mathrm{C}\right)$, and washed three times. Isolated luteal cells were filtered through nylon mesh $(40 \mu \mathrm{m}$ in diameter) and resuspended in fresh F-12 medium. The cells were counted using a haemocytometer, and their viability $(\sim 90 \%)$ was determined by $0.4 \%$ trypan blue dye exclusion.

Granulosa and theca interna cells were isolated from large follicles (diameter $>6 \mathrm{~mm}$ ) without signs of atresia. Granulosa cells were aspirated with a syringe and additionally washed out with a strong stream of media directed to the internal wall of the follicle [26]. The theca interna layer was scraped off from granulosa cells and enzymatically dispersed in $0.25 \%$ trypsin solution [27]. Dispersed cells were centrifuged $(800 \times \mathrm{g}$ for $10 \mathrm{~min})$ and washed two and three times to isolate granulosa and theca interna cells, respectively. The cells were filtered through nylon mesh $(40 \mu \mathrm{m}$ in diameter) and resuspended in Eagle's medium enriched with BSA (5\%) and antibiotics. The cells were counted using a haemocytometer, and their viability ( $98 \%$ ) was determined by $0.4 \%$ trypan blue dye exclusion. Some of granulosa and theca interna cells $\left(5 \times 10^{6}\right.$ viable cells within each experiment) were immediately resuspended in TRIzol reagent (Invitrogen, USA) and stored at $-80^{\circ} \mathrm{C}$ until processing for RNA analysis.

\subsection{Total RNA Isolation, cDNA Synthesis and Quantitative} Real-Time PCR. Total RNA was extracted from luteal tissues from days 2-3, 10-12, and 14-16 of the oestrous cycle using the Absolutely RNA Miniprep Kit (Stratagene, USA). In the case of granulosa and theca cells total RNA was extracted using the TRIzol reagent. RNA concentration and quality were determined spectrophotometrically (NanoDrop ND1000, NanoDrop Technologies Inc., USA). Approximately $1 \mu \mathrm{g}$ of RNA was reverse-transcribed into cDNA in a total volume of $20 \mu \mathrm{L}$ with $0.5 \mu \mathrm{g}$ oligo $(\mathrm{dt})_{15}$ primer (Roche, Germany) using the Omniscript RT Kit (Qiagen, USA) at $37^{\circ} \mathrm{C}$ for one hour and was terminated by incubation at $93^{\circ} \mathrm{C}$ for $5 \mathrm{~min}$. Quantitative real-time PCR analysis was performed using a PCR System 7300 (Applied Biosystems, USA). Sense and antisense primers (adiponectin, cyclophilin A) were chosen according to Lord et al. [8] study. Forward and reverse primers for glyceraldehyde (GAPDH) were used according to Nitkiewicz et al. paper [24]. The chosen primers were as follows: adiponectin forward: $5^{\prime}$ ATGATGTCACCACTGGCAAATTC-3', reverse: $5^{\prime}$-GACCGTGACGTGGAAGGAGA-3'; cyclophilin A, forward: $5^{\prime}$-GCACTGGTGGCAAGTCCAT-3', reverse: $5^{\prime}$-AGGACCCGTATGCTTCAGGA-3'; GAPDH forward: 5' -CCTTCATTGACCTCCACTACATGGT-3', reverse: $5^{\prime}$-CCACAACATACGTAGCACCAGCATC-3'. Adiponectin primers (access no: AY135647) were complementary to positions 514-536 (F) and 565-584 (R) of pig adiponectin gene sequence; cyclophilin A primers (access no: AY266299) were complementary to positions 219237 (F) and 269-299 (R) of pig cyclophilin A gene sequence, GAPDH primers (access no: U48832) were complementary 
to positions 61-85 (F) and 219-243 (R) of pig GAPDH. A constitutively expressed genes, cyclophilin A and GAPDH, were used as the internal control to verify the quantitative real-time PCR. To ensure that cyclophilin A and GAPDH were the suitable reference genes for this study, we revealed that there were no statistically significant differences in $\mathrm{Ct}$ values between the examined ovarian structures throughout all investigated stages of the oestrous cycle. Both of the housekeeping genes were also indicated as suitable reference genes (internal controls) in the independent studies [28]. The PCR reaction included $20 \mathrm{ng}$ cDNA, $900 \mathrm{nM}$ (adiponectin forward), $300 \mathrm{nM}$ (adiponectin reverse, cyclophilin A forward and reverse) and $60 \mathrm{nM}$ (GAPDH forward and reverse) primers, $12.5 \mu \mathrm{L}$ SYBR Green PCR Master Mix (Applied Biosystems, USA), and RNase free water in a final volume of $25 \mu \mathrm{L}$. Quantitative real-time PCR cycling conditions were as follows: initial denaturation and enzyme activation at $95^{\circ} \mathrm{C}$ for $10 \mathrm{~min}$, followed by 40 cycles of denaturation at $95^{\circ} \mathrm{C}$ for $15 \mathrm{~s}$ and annealing at $59^{\circ}$ for $1 \mathrm{~min}$. Negative controls were performed in which water was substituted for cDNA, or reverse transcription was not performed prior to PCR. All samples were amplified in duplicate. The specificity of amplification was tested at the end of the PCR by melting-curve analysis. Product purity was confirmed by electrophoresis. Calculation of relative expression levels of adiponectin was conducted based on the comparative cycle threshold method $(\Delta \Delta \mathrm{Ct})[29]$ and normalized using the geometrical mean of reference genes expression levels: GAPDH and cyclophilin A.

2.4. Western Blotting. Western blotting analysis was performed as described by Smolinska et al. [30]. Briefly, equal amounts of porcine corpora lutea as well as granulosa and theca cells lysats $(10 \mu \mathrm{g})$ were resolved by SDS-PAGE on $12.5 \%$ polyacrylamide gel and then transferred to a nitrocellulose membranes (Whatman, USA). Blots were blocked for $5 \mathrm{~h}$ at $4^{\circ} \mathrm{C}$ in $1 \times$ TBST containing $5 \%$ skimmed milk powder and then incubated overnight at $4^{\circ} \mathrm{C}$ with the rabbit polyclonal adiponectin antibodies at the dilution of $1: 150$ (Santa Cruz Biotechnology, USA) or rabbit polyclonal actin antibodies (Sigma, USA) diluted 1:200, which were used as an internal control for equal loading and to quantify porcine adiponectin protein. To identify immunoreactive bands, membranes were incubated for $1.5 \mathrm{~h}$ at room temperature with mouse anti-rabbit IgG for adiponectin (Sigma, USA; diluted 1:2000), goat anti-rabbit IgG for actin (diluted 1:5000) conjugated with alkaline phosphatase (Santa Cruz Biotechnology, USA). Nonspecific foetal calf serum (MP Biomedicals, USA) was used instead of primary antibodies to produce negative control blots. The immunocomplexes were visualized using 4-nitroblue tetrazolium chloride (NBT) and 5-bromo-4-chloro-3-indolyl phosphate (BCIP), according to the manufacture's protocol (Promega, USA). The results of Western blotting were quantified by densitometric scanning of immunoblots with GelScan for Windows ver. 1.45 software (Kucharczyk, Poland). Data were expressed as a ratio of adiponectin protein relative to actin protein in arbitrary optical density units.
2.5. In Vitro Cultures of Luteal, Granulosa, and Theca Interna Cells. Luteal cells (250000/1 mL medium) were resuspended in F-12 medium enriched with foetal calf serum (FCS; 20\%), BSA (1\%) and antibiotics and preincubated for 48 hours in a humidified incubator with $95 \%$ air and $5 \% \mathrm{CO}_{2}$ atmosphere. The serum-containing medium was discarded, and the cells were washed using serum-free F-12 medium. After washing, luteal cells were cultured for 24 hours in F-12 medium with BSA (1\%) and antibiotics, with or without treatment agents.

Granulosa and theca interna cells (250000/1 mL medium) were resuspended in Eagle's medium supplemented with 10\% FCS, 5\% BSA, and antibiotics. After 24 hours of preincubation, the medium was discarded, and the cells were washed and cultured for 24 hours in Eagle's medium with 5\% BSA and antibiotics, with or without treatment reagents.

The cultured cells were treated with 1 or $10 \mu \mathrm{g} / \mathrm{mL}$ of recombinant human adiponectin (Biovendor, USA) alone or in combination with insulin (granulosa and theca interna cells; 10 ng/mL; Sigma, USA), FSH (granulosa cells; 10 ng/mL; NHPP, USA) and LH (theca interna cells; $10 \mathrm{ng} / \mathrm{mL}$; NHPP, USA), and combination of those treatments (insulin $+\mathrm{FSH}$ for granulosa cells and insulin $+\mathrm{LH}$ for theca interna cells). Adiponectin doses used in the experiment were close to physiological concentrations of this hormone in the porcine blood [22]. Luteal cells were cultured only with adiponectin (both doses) without other stimulators. Those cells are thought to be generally more autonomic than follicular cells which is a reason of luteal cells' hard response to stimulators [31-33]. The Alamar blue test revealed that none of the treatments affected the viability of the cultured cells. All incubations were performed in duplicate. Following incubation, the media were harvested, centrifuged $(800 \times \mathrm{g}$ for $10 \mathrm{~min})$, and the supernatants were collected and stored at $-20^{\circ} \mathrm{C}$ until analyses of progesterone (cultures of luteal, theca interna, and granulosa cells), oestradiol (cultures of theca interna and granulosa cells), androstenedione, and testosterone (cultures of theca interna cells).

2.5.1. Radioimmunoassays of Steroid Hormones. Progesterone $\left(\mathrm{P}_{4}\right)$ was analysed according to the method described by Ciereszko et al. [34], oestradiol $\left(\mathrm{E}_{2}\right)$ was determined according to the method of Hotchkiss et al. [35] modified by Kotwica [36], androstenedione $\left(\mathrm{A}_{4}\right)$ as described by Dziadkowiec et al. [37], and testosterone ( $\mathrm{T}$ ) according to Kotwica and Williams [38]. Cross-reactivities of the antiserum against $\mathrm{P}_{4}$ have been published previously [37]. The specificity of the antibodies against $A_{4}, T$, and $E_{2}$ has been reported by Ciereszko et al. [39] and Szafranska et al. [40]. The sensitivities of the assays for $\mathrm{P}_{4}$ and $\mathrm{A}_{4}$ were $1 \mathrm{pg} / \mathrm{mL}$ and for $\mathrm{E}_{2}$ and $\mathrm{T}$ were $0.5 \mathrm{pg} / \mathrm{mL}$. Intra- and interassay coefficients of variation of the $\mathrm{P}_{4}, \mathrm{E}_{2}, \mathrm{~A}_{4}$, and $\mathrm{T}$ assays were $0.91 \%, 0.7 \%, 0.81 \%, 0.97 \%$ and $8.5 \%, 10.1 \%$, $14.2 \%$, and $7.8 \%$, respectively.

2.6. Statistical Analysis. Data from real-time analysis and Western blot were analysed by one-way ANOVA and least significant difference (LSD) post hoc test and are reported as the means \pm SEM from five independent observations. All data concerning in vitro cell cultures were analysed by 
ANOVA for repeated measurements and least significant difference (LSD) post hoc test and are reported as the means \pm SEM from five (for all types of cells) independent observations. Each experiment was performed on different day using separate pool of luteal or follicular cells. Statistical analysis was performed using the Statistica program (StatSoft Inc., Tulsa, USA). Values for $P<0.05$ were considered statistically significant.

\section{Results}

3.1. Adiponectin Gene Expression. The expression of adiponectin mRNA was significantly higher in corpora lutea during all investigated days of the luteal phase than in theca interna cells isolated on days $17-19$ of the cycle $(P<0.05)$. No significant differences were noted in adiponectin gene expression in granulosa cells compared with theca interna cells and CLs (Figure 1(a)).

3.2. Concentration of Adiponectin Protein. In general, adiponectin protein concentration in the porcine ovary was higher in the luteal phase than in the follicular phase. In particular, the adiponectin protein content was the greatest in CLs from days 2-3 in comparison with CLs and follicular cells from the remaining stages of the oestrous cycle $(P<$ $0.01)$. Within the luteal phase adiponectin concentration was the lowest in CLs during days 10-12 $(P<0.01)$. There was no significant differences in protein expression between granulosa and theca interna cells (Figure 1(b)).

3.3. Effects of Adiponectin on Progesterone Secretion by Luteal Cells. Treatment of luteal cells from days 10-12 of the oestrous cycle with adiponectin at both doses $(1 \mu \mathrm{g} / \mathrm{mL}$; $10 \mu \mathrm{g} / \mathrm{mL})$ resulted in significant $(P<0.05)$ decrease in progesterone secretion (Figure 2). Adiponectin at any dose did not affect $\mathrm{P}_{4}$ secretion by luteal cells collected on days 2-3 and 14-16 (data not shown).

\subsection{Effects of Adiponectin on Progesterone and Oestradiol} Secretion by Follicular Granulosa Cells. Adiponectin at the higher dose $(10 \mu \mathrm{g} / \mathrm{mL})$ in combination with insulin provoked the increase in $\mathrm{P}_{4}$ secretion in comparison with the cells stimulated by insulin alone $(P<0.05)$. In contrast, there was no effect of adiponectin (both doses) on FSH- and FSH + insulin-induced production of $\mathrm{P}_{4}$ in porcine granulosa cells (Figure 3 ). Basal secretion of $\mathrm{P}_{4}$ was unaffected independently on adiponectin dose (data not shown).

Adiponectin at the higher dose $(10 \mu \mathrm{g} / \mathrm{mL})$ increased basal secretion of $\mathrm{E}_{2}(P<0.05)$ (Figure 4$)$. Adiponectin did not change secretion of $\mathrm{E}_{2}$ by granulosa cells cultured with insulin and/or FSH (data not shown).

3.5. Effects of Adiponectin on Progesterone, Oestradiol, Androstenedione, and Testosterone Secretion by Follicular Theca Interna Cells. Adiponectin at both doses reduced basal secretion of T by porcine theca interna cells $(P<0.05)$ (Figure 5$)$. The effect of adiponectin on basal $\mathrm{P}_{4}, \mathrm{E}_{2}$, and $\mathrm{A}_{4}$ release was negligible (data not shown).
Adiponectin $(10 \mu \mathrm{g} / \mathrm{mL})$ decreased $\mathrm{LH}+$ insulin-stimulated secretion of $\mathrm{P}_{4}$ by theca interna cells $(P<0.05)$. There was no effect of adiponectin on $\mathrm{LH}$ - or insulin-induced production of $\mathrm{P}_{4}$ by these cells (Figure 6(a)).

Adiponectin did not influence LH- or insulin-stimulated secretion of $\mathrm{E}_{2}$ by theca interna cells. However, $\mathrm{LH}+$ insulininduced secretion of $\mathrm{E}_{2}$ by the cells was increased in response to the higher dose $(10 \mu \mathrm{g} / \mathrm{mL})$ of adiponectin $(P<0.05)$ (Figure 6(b)).

Secretion of $\mathrm{A}_{4}$ by theca interna cells was inhibited by combination of adiponectin $(10 \mu \mathrm{g} / \mathrm{mL})$ with insulin compared to insulin alone $(P<0.05)$. There was no effect of adiponectin on $\mathrm{LH}$-induced production of $\mathrm{A}_{4}$. Adiponectin at the lower dose $(1 \mu \mathrm{g} / \mathrm{mL})$ increased $\mathrm{LH}+$ insulin-induced $\mathrm{A}_{4}$ secretion by the cells $(P<0.05)$ (Figure 6(c)). Induced secretion of $\mathrm{T}$ was not changed under adiponectin influence (data not shown).

\section{Discussion}

This is the first ever study to demonstrate the changes in adiponectin gene and protein expression in the porcine ovary throughout the oestrous cycle. Our results indicate that adiponectin is more highly expressed in luteal cells derived from ovaries in all examined stages of the luteal phase than in follicular granulosa and theca interna cells. Adiponectin was also found to affect basal and stimulated secretion of steroid hormones by porcine ovarian cells.

In addition to porcine ovarian structures, adiponectin gene expression and the presence of the hormone protein were also found in woman theca interna cells [16] and in theca interna cells, granulosa cells, corpora lutea, and oocytes of rats [17] and cows [18, 19]. Singh and Krishna [41] localized the adiponectin protein in bat ovarian structures that showed positive immunostaining in theca interna cells, oocytes of growing follicles, and the corpus luteum. The expression of adiponectin gene and protein was also determined in porcine granulosa cells of prepubertal gilts [8]. The levels of adiponectin expression and also its receptors seem to vary subject to cell type and the stage of follicle and corpora lutea development. In the bovine ovary, the expression of adiponectin and its both receptors was lower in granulosa cells than in theca interna cells and oocytes [18]. Contrary results were presented by Ortega et al. [42] who observed the highest levels of adiponectin expression in granulosa cells of sheep ovaries. Throughout follicular development, adiponectin mRNA increased in granulosa cells and decreased in theca interna cells of cows. In the corpora lutea, the discussed hormone was most highly expressed during luteolysis. Bovine theca interna cells derived from large follicles revealed higher expression of both receptors than cells isolated from medium-sized and small follicles, indicating that follicular growth influences the transcript levels of adiponectin receptors [18].

The synthesis of ovarian adiponectin and the expression of AdipoR1 and AdipoR2 are probably hormonally controlled, as suggested by an increase in adiponectin concentrations in ovarian follicular fluid of women administrated 


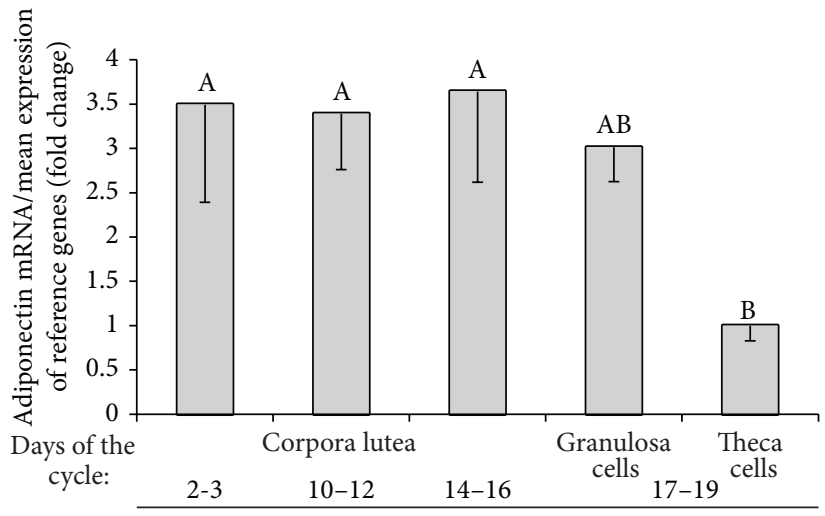

(a)
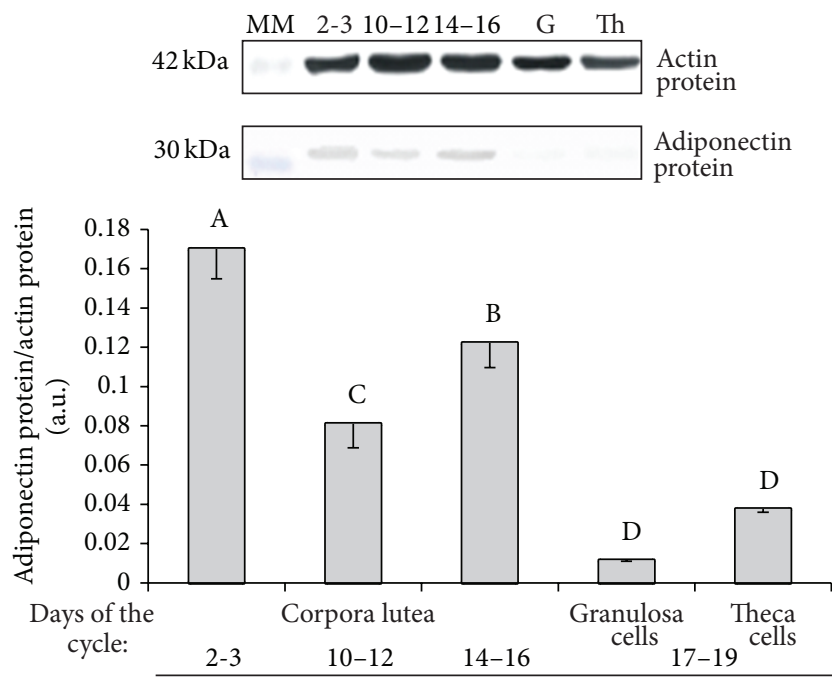

(b)

FIgURE 1: (a) Adiponectin mRNA expression determined by quantitative real-time PCR in porcine corpora lutea, granulosa cells, and theca interna cells harvested on days 2-3, 10-12, 14-16, and 17-19 of the oestrous cycle. The results are expressed as means \pm S.E.M. $(n=5)$. Bars with different letters at the top are different $(P<0.05)$. (b) Adiponectin protein expression determined by Western blotting analysis in porcine corpora lutea, granulosa, and theca interna cells on days 2-3, 10-12, 14-16, and 17-19 of the oestrous cycle. Upper panel: representative immunoblots (MM-molecular marker, G-granulosa cells, Th-theca interna cells); lower panel: densitometric analysis of adiponectin protein relative to actin protein. The noted values are expressed as means \pm S.E.M. in arbitrary optical density units $(n=5)$. Bars with different letters at the top are different $(P<0.01)$.

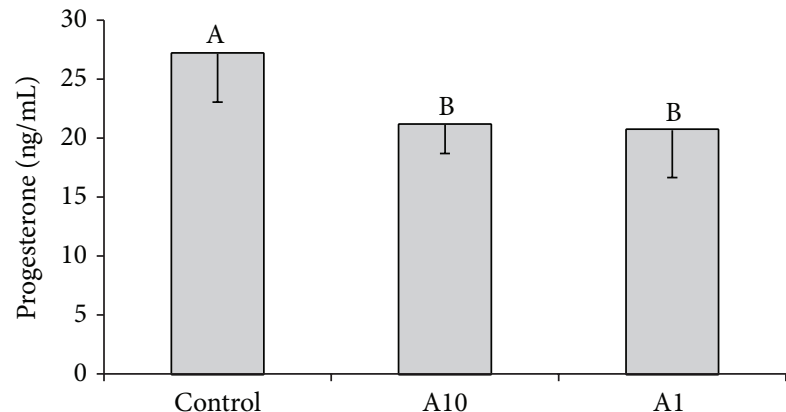

FIGURE 2: The effect of adiponectin $(10 \mu \mathrm{g} / \mathrm{mL}-\mathrm{A} 10$ and $1 \mu \mathrm{g} / \mathrm{mL}-\mathrm{A} 1)$ on basal progesterone secretion by cultured luteal cells collected on days 10-12 of the oestrous cycle. Bars with different superscripts are significantly different $(P<0.05)$. Result are means \pm S.E.M. of five replicates.

$\mathrm{LH}$ in the in vitro fertilization procedure [43]. Following PMSG pretreatment, an injection of hCG also significantly increased the expression of adiponectin and AdipoR1 (but not AdipoR2) genes in rat ovaries [17]. In bovine theca interna cells, LH increased the concentrations of AdipoR2 mRNAs, whereas IGF-I suppressed the expression of the above gene [44]. The results of the present study seem to confirm the hypothesis that adiponectin production is regulated hormonally. Higher levels of adiponectin gene and protein expression during the luteal phase and lower expression levels during the follicular phase could point to the stimulatory effect of progesterone and the inhibitory influence of oestradiol on ovarian adiponectin production.

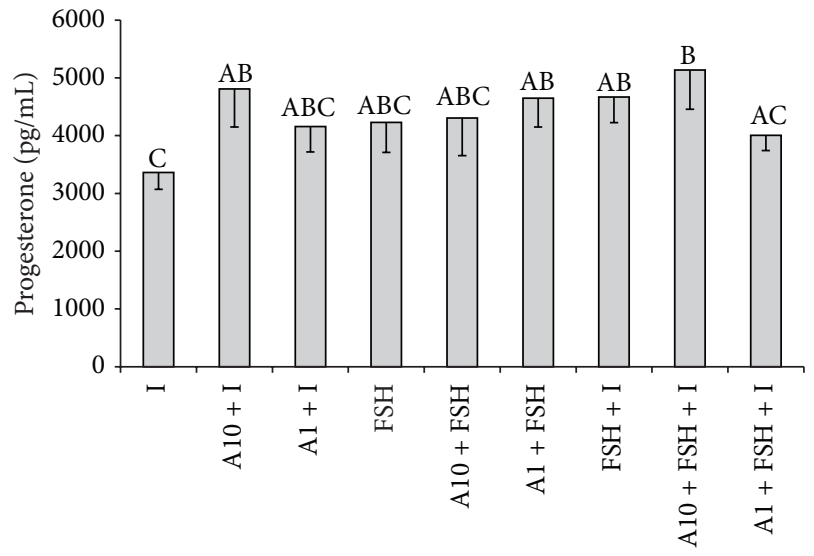

FIGURE 3: The effect of adiponectin $(10 \mu \mathrm{g} / \mathrm{mL}-\mathrm{A} 10$ and $1 \mu \mathrm{g} / \mathrm{mL}-$ A1) on insulin-stimulated (I; $10 \mathrm{ng} / \mathrm{mL}$ ) and/or FSH-stimulated (10 ng/mL) progesterone secretion by cultured granulosa cells collected on days 17-19 of the oestrous cycle. Bars with different superscripts are significantly different $(P<0.05)$. Results are means \pm S.E.M. of five replicates.

In our previous study, adiponectin serum concentrations were higher during the luteal phase than the follicular phase [22], which suggests that ovarian steroids influence plasma adiponectin levels. In this study, we examined the effect of adiponectin in vitro on steroid secretion. The results of our in vitro studies and the presence of both adiponectin receptors in porcine ovaries indicate that adiponectin may directly affect ovarian steroidogenesis. In fact, progesterone 


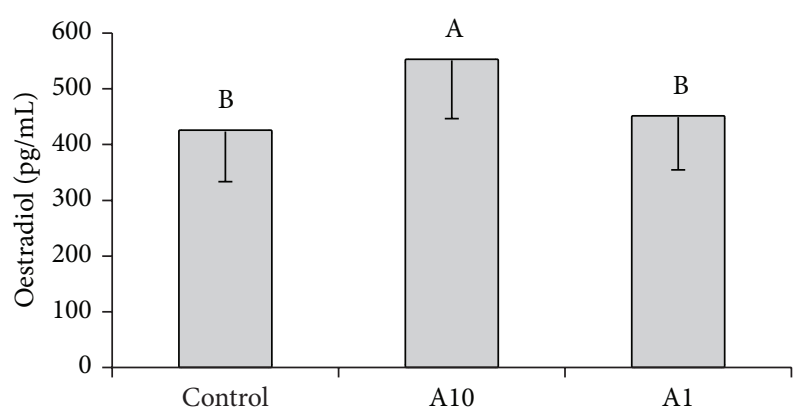

FIGURE 4: The effect of adiponectin $(10 \mu \mathrm{g} / \mathrm{mL}-\mathrm{A} 10$ and $1 \mu \mathrm{g} / \mathrm{mL}-\mathrm{A} 1)$ on basal oestradiol secretion by cultured granulosa cells collected on days 17-19 of the oestrous cycle. Bars with different superscripts are significantly different $(P<0.05)$. Results are means \pm S.E.M. of five replicates.

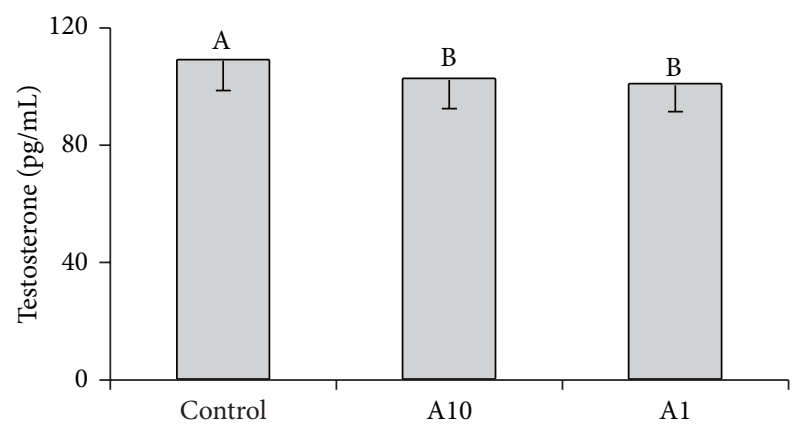

FIGURE 5: The effect of adiponectin $(10 \mu \mathrm{g} / \mathrm{mL}-\mathrm{A} 10$ and $1 \mu \mathrm{g} / \mathrm{mL}-$ A1) on basal testosterone secretion by cultured theca interna cells collected on days 17-19 of the oestrous cycle. Bars with different superscripts are significantly different $(P<0.05)$. Results are means \pm S.E.M. of five replicates.

secretion decreased due to adiponectin's influence on luteal cells in mid-luteal phase (days 10-12). Greater variations in adiponectin action were observed in porcine follicular cells. Induced progesterone production increased in granulosa cells and decreased in theca interna cells. Basal testosterone output and insulin-induced androstenedione secretion were inhibited, while $\mathrm{LH}+$ insulin-stimulated release of androstenedione was enhanced by adiponectin. The effect of adiponectin on ovarian steroidogenesis was also suggested in studies of cows, rats, and humans. Adiponectin was found to inhibit insulin-induced secretion of progesterone and oestradiol by bovine granulosa cells [19]. In a study of theca interna cells of bovine ovaries, Lagaly et al. [44] observed that adiponectin decreased $\mathrm{LH}+$ insulin-induced production of progesterone. The above authors also noted that adiponectin inhibited the mRNA expression of LH receptor in granulosa cells. Granulosa cells of rats and women treated with IGFI responded to adiponectin by increasing progesterone and oestradiol secretion $[16,17]$. In the cited studies, adiponectin did not influence FSH-induced production of progesterone and oestradiol in human and rat granulosa cells which is consistent with the response of porcine cells noted in this study.
It seems that adiponectin affects ovarian functions by binding AdipoR1 and AdipoR2, in two ways. An experiment where RNAi was used to block AdipoR1 and AdipoR2 expression in the KGN cell line derived from human granulosa cells contributed to new information about adiponectin's role in the ovaries. The absence of AdipoR1 in the analysed cells enhanced apoptosis, whereas the elimination of AdipoR2 reduced FSH- and IGF-I-induced the production of progesterone and oestradiol and inhibited mitogen-activated kinase activity, relative to control, in response to adiponectin or FSH treatment [45]. The above results suggest that AdipoR1 is more involved in the survival of granulosa cells, whereas AdipoR2 regulates steroidogenesis through MAPK activation. The influence of adiponectin on the ovaries of sexually mature pigs has not been studied to date, but the response of granulosa cells derived from prepubertal gilts to the analysed hormone was described by Ledoux et al. [46]. The above authors observed higher levels of cyclooxygenase2 , prostaglandin E synthase, and VEGF gene expression in cells primed with adiponectin, an increase in the expression of the StAR gene and a decrease in the expression of the P450 aromatase gene. Adiponectin's impact on steroidogenesis was also investigated in very distant species. Singh and Krishna [47] documented the influence of adiponectin in vespertilionid bats. Adiponectin treatment contributed to an increase in progesterone levels and a decrease in androstenedione and oestradiol plasma concentrations in comparison with control bats. In the same study, adiponectin treatment increased $\mathrm{P} 450_{\mathrm{SCC}}$ and $3 \beta$-HSD enzyme levels but decreased aromatase, StAR and LH-R levels in comparison with controls.

The involvement of adiponectin in steroidogenesis control is not restricted to the ovaries. Its activity was also noted in the testes and adrenal glands. An in vitro study by Caminos et al. [48] demonstrated that adiponectin significantly inhibited basal and hCG-stimulated testosterone secretion by testicular explants. In another study, adiponectin decreased corticosterone secretion by freshly isolated rat adrenocortical cells but did not affect aldosterone production [49]. An opposite effect was observed in human adrenocortical H295R cells. Adiponectin treatment enhanced cortisol secretion, which was accompanied by increased expression of steroidogenic pathway genes, including StAR protein expression, via ERK1/2 and AMPK-dependent pathways [50].

In addition to its direct effects on steroidogenesis in the ovary, adiponectin could also indirectly affect gonadal functions by controlling the secretory activity of the hypothalamus and pituitary. A study by Wen et al. [51] demonstrated the inhibition of GnRH release from GT1-7 hypothalamic GnRH neurons after the administration of adiponectin. In in vivo study by Cheng et al. [52] adiponectin also lowered GnRH secretion by activating the AMPK and inhibiting the ERK pathways. In the lower branch of the HPG axis, adiponectin exhibited a general inhibitory effect on gonadotrophins secretion. The release of LH from rat pituitary cells and the murine $\mathrm{L} \beta \mathrm{T} 2$ cell line was decreased after the administration of adiponectin alone and in combination with $\mathrm{GnRH}[53,54]$. In vivo observations also demonstrated an inhibitory effect of adiponectin on LH secretion: the intravenous administration of the adenovirus expressing the adiponectin gene to male 


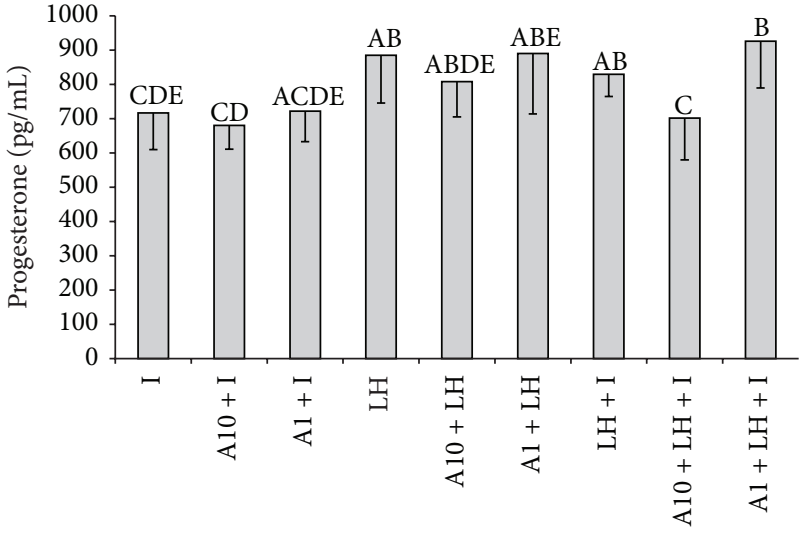

(a)

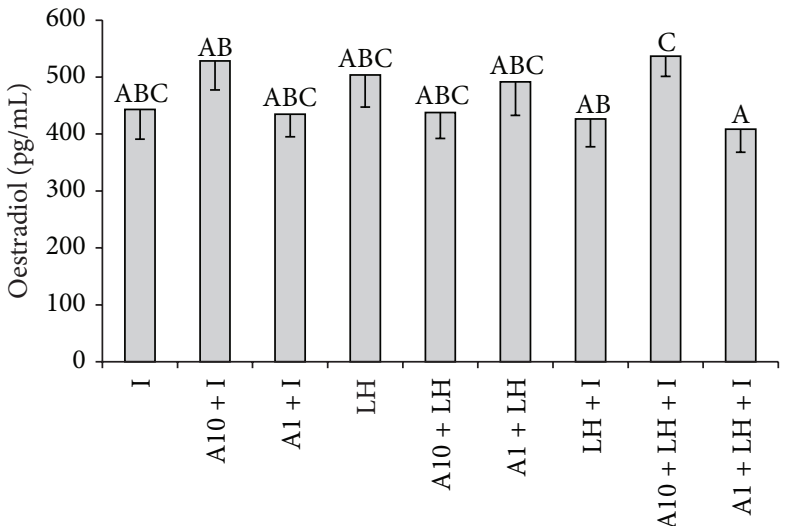

(b)

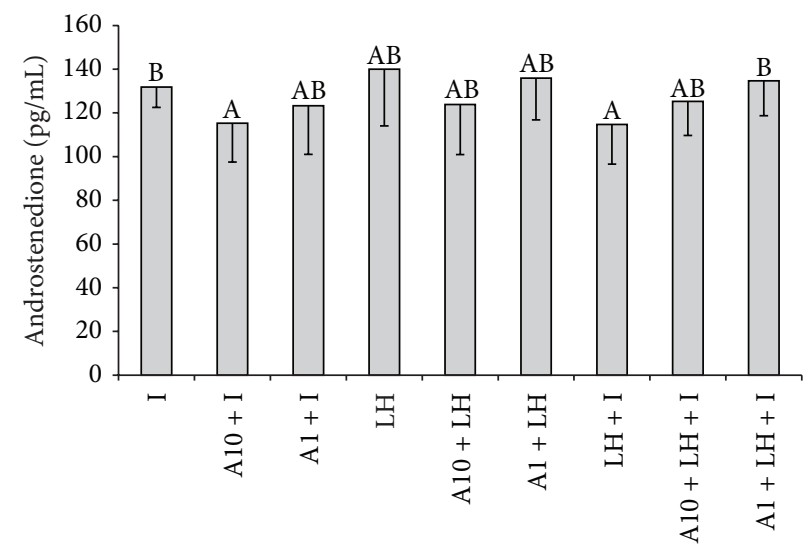

(c)

FIGURE 6: The effect of adiponectin (10 $\mu \mathrm{g} / \mathrm{mL}-\mathrm{A} 10$ and $1 \mu \mathrm{g} / \mathrm{mL}-\mathrm{Al})$ on insulin-stimulated (I; $10 \mathrm{ng} / \mathrm{mL})$ and/or LH-stimulated (10 ng/mL) (a) progesterone, (b) oestradiol, and (c) androstenedione secretion by cultured theca interna cells collected on days 17-19 of the oestrous cycle. Bars with different superscripts are significantly different $(P<0.05)$. Results are means \pm S.E.M. of five replicates.

mice decreased plasma LH levels without changes in FSH levels [54]. The inhibitory influence of adiponectin on LH secretion could be attributed to a decrease in GnRH receptor gene expression in the pituitary [53].

\section{Conclusions}

The presence of adiponectin mRNA and protein in porcine ovaries observed in this study as well as the presence of adiponectin receptors 1 and 2 in the gonads noted in our previous work could provide evidence for auto/paracrine actions of the analysed hormone. The variations in adiponectin gene and protein expression during the oestrous cycle indicate that adiponectin expression is determined by the hormonal status of pigs. The effect of adiponectin on ovarian steroidogenesis suggests that this adipokine influences reproductive functions in pigs. Yet for definitive conclusions to be drawn, especially concerning precise localization of adiponectin mRNA and protein in different ovarian structures, intracellular mechanisms of adiponectin influence on the gonadal steroidogenesis and its possible effect on other functions of the ovaries, further studies are required to determine the role of adiponectin in ovarian physiology.

\section{Conflict of Interests}

The authors declare that there is no conflict of interests regarding the publication of this paper.

\section{Acknowledgment}

This research was supported by National Science Centre (Project no. 2011/01/B/NZ4/01596).

\section{References}

[1] P. Trayhurn and I. S. Wood, "Adipokines: inflammation and the pleiotropic role of white adipose tissue," British Journal of Nutrition, vol. 92, no. 3, pp. 347-355, 2004.

[2] P. E. Scherer, S. Williams, M. Fogliano, G. Baldini, and H. F. Lodish, "A novel serum protein similar to Clq, produced exclusively in adipocytes," Journal of Biological Chemistry, vol. 270, no. 45, pp. 26746-26749, 1995. 
[3] E. Hu, P. Liang, and B. M. Spiegelman, "AdipoQ is a novel adipose-specific gene dysregulated in obesity," Journal of Biological Chemistry, vol. 271, no. 18, pp. 10697-10703, 1996.

[4] Y. Nakano, T. Tobe, N.-H. Choi-Miura, T. Mazda, and M. Tomita, "Isolation and characterization of GBP28, a novel gelatin-binding protein purified from human plasma," Journal of Biochemistry, vol. 120, no. 4, pp. 803-812, 1996.

[5] K. Maeda, K. Okubo, I. Shimomura, T. Funahashi, Y. Matsuzawa, and K. Matsubara, "cDNA cloning and expression of a novel adipose specific collagen-like factor, apM1 (adipose most abundant gene transcript 1)," Biochemical and Biophysical Research Communications, vol. 221, no. 2, pp. 286-289, 1996.

[6] M. E. Trujillo and P. E. Scherer, "Adiponectin - Journey from an adipocyte secretory protein to biomarker of the metabolic syndrome," Journal of Internal Medicine, vol. 257, no. 2, pp. 167175, 2005.

[7] T. Yamauchi, J. Kamon, Y. Minokoshi et al., "Adiponectin stimulates glucose utilization and fatty-acid oxidation by activating AMP-activated protein kinase," Nature Medicine, vol. 8, no. 11, pp. 1288-1295, 2002.

[8] E. Lord, S. Ledoux, B. D. Murphy, D. Beaudry, and M. F. Palin, "Expression of adiponectin and its receptors in swine," Journal of Animal Science, vol. 83, no. 3, pp. 565-578, 2005.

[9] Y. Qi, N. Takahashi, S. M. Hileman et al., "Adiponectin acts in the brain to decrease body weight," Nature Medicine, vol. 10, no. 5, pp. 524-529, 2004.

[10] A. Gavrila, J. L. Chan, N. Yiannakouris et al., "Serum Adiponectin Levels Are Inversely Associated with Overall and Central Fat Distribution but Are Not Directly Regulated by Acute Fasting or Leptin Administration in Humans: Cross-Sectional and Interventional Studies," Journal of Clinical Endocrinology and Metabolism, vol. 88, no. 10, pp. 4823-4831, 2003.

[11] M. Fasshauer and R. Paschke, "Regulation of adipocytokines and insulin resistance," Diabetologia, vol. 46, no. 12, pp. 15941603, 2003.

[12] A. Rak and E. L. Gregoraszczuk, "Modulatory effect of ghrelin in prepubertal porcine ovarian follicles," Journal of Physiology and Pharmacology, vol. 59, no. 4, pp. 781-793, 2008.

[13] T. Kaminski, N. Smolinska, A. Gajewska et al., "Leptin and long form of leptin receptor genes expression in the hypothalamus and pituitary during the luteal phase and early pregnancy in pigs," Journal of Physiology and Pharmacology, vol. 57, no. 1, pp. 95-108, 2006.

[14] T. Kaminski, N. Smolinska, A. Nitkiewicz, and J. Przala, "Expression of orexin receptors 1 (OX1R) and 2 (OX2R) in the porcine pituitary during the oestrous cycle," Animal Reproduction Science, vol. 117, no. 1-2, pp. 111-118, 2010.

[15] T. Kaminski, N. Smolinska, A. Nitkiewicz, and J. Przala, "Expression of orexin receptors 1 (OX1R) and 2 (OX2R) in the porcine hypothalamus during the oestrous cycle," Journal of Physiology and Pharmacology, vol. 61, no. 3, pp. 363-371, 2010.

[16] C. Chabrolle, L. Tosca, C. Ramé, P. Lecomte, D. Royère, and J. Dupont, "Adiponectin increases insulin-like growth factor Iinduced progesterone and estradiol secretion in human granulosa cells," Fertility and Sterility, vol. 92, no. 6, pp. 1988-1996, 2009.

[17] C. Chabrolle, L. Tosca, and J. Dupont, "Regulation of adiponectin and its receptors in rat ovary by human chorionic gonadotrophin treatment and potential involvement of adiponectin in granulosa cell steroidogenesis," Reproduction, vol. 133, no. 4, pp. 719-731, 2007.
[18] M. R. Tabandeh, A. Hosseini, M. Saeb, M. Kafi, and S. Saeb, "Changes in the gene expression of adiponectin and adiponectin receptors (AdipoR1 and AdipoR2) in ovarian follicular cells of dairy cow at different stages of development," Theriogenology, vol. 73, no. 5, pp. 659-669, 2010.

[19] V. Maillard, S. Uzbekova, F. Guignot et al., "Effect of adiponectin on bovine granulosa cell steroidogenesis, oocyte maturation and embryo development," Reproductive Biology and Endocrinology, vol. 8, article 23, 2010.

[20] A. Böttner, J. Kratzsch, G. Müller et al., "Gender differences of adiponectin levels develop during the progression of puberty and are related to serum androgen levels," Journal of Clinical Endocrinology and Metabolism, vol. 89, no. 8, pp. 4053-4061, 2004.

[21] T. P. Combs, A. H. Berg, M. W. Rajala et al., "Sexual differentiation, pregnancy, calorie restriction, and aging affect the adipocyte-specific secretory protein adiponectin," Diabetes, vol. 52, no. 2, pp. 268-276, 2003.

[22] A. Maleszka, N. Smolinska, A. Nitkiewicz et al., "Expression of adiponectin receptors 1 and 2 in the ovary and concentration of plasma adiponectin during the oestrous cycle of the pig," Acta Veterinaria Hungarica, 2014.

[23] E. L. Akins and M. C. Morrissette, "Gross ovarian changes during estrous cycle of swine," American Journal of Veterinary Research, vol. 29, no. 10, pp. 1953-1957, 1968.

[24] A. Nitkiewicz, N. Smolinska, J. Przala, and T. Kaminski, "Expression of orexin receptors 1 (OX1R) and 2 (OX2R) in the porcine ovary during the oestrous cycle," Regulatory Peptides, vol. 165, no. 2-3, pp. 186-190, 2010.

[25] T. Kaminski, G. Siawrys, S. Okrasa, and J. Przala, "Action of the opioid agonist FK 33-824 on porcine small and large luteal cells from the mid-luteal phase: Effect on progesterone, cAMP, cGMP and inositol phosphate release," Animal Reproduction Science, vol. 56, no. 3-4, pp. 245-257, 1999.

[26] T. Kaminski, G. Siawrys, I. Bogacka, S. Okrasa, and J. Przala, "The Influence of Opioid Peptides on Steroidogenesis in Porcine Granulosa Cells," Reproduction in Domestic Animals, vol. 39, no. 1, pp. 25-32, 2004.

[27] T. Kaminski, G. Siawrys, I. Bogacka, S. Okrasa, and J. Przala, "The regulation of steroidogenesis by opioid peptides in porcine theca cells," Animal Reproduction Science, vol. 78, no. 1-2, pp. 7184, 2003.

[28] H. Zhong and J. W. Simons, "Direct comparison of GAPDH, $\beta$ actin, cyclophilin, and 28S rRNA as internal standards for quantifying RNA levels under hypoxia," Biochemical and Biophysical Research Communications, vol. 259, no. 3, pp. 523-526, 1999.

[29] K. J. Livak and T. D. Schmittgen, "Analysis of relative gene expression data using real-time quantitative PCR and the $2^{-\Delta \Delta C}$ T method," Methods, vol. 25, no. 4, pp. 402-408, 2001.

[30] N. Smolinska, T. Kaminski, G. Siawrys, and J. Przala, "Long form of leptin receptor gene and protein expression in the porcine ovary during the estrous cycle and early pregnancy," Reproductive Biology, vol. 7, no. 1, pp. 17-39, 2007.

[31] E. L. Gregoraszczuk, "Effect of various doses of FSH upon luteal cell function in tissue culture," Endocrinologia Experimentalis, vol. 23, no. 3, pp. 195-203, 1989.

[32] M. Hunter g., "Responsiveness in vitro of porcine luteal tissue recovered at two stages of the luteal phase," Journal of Reproduction and Fertility, vol. 63, no. 2, pp. 471-476, 1981.

[33] M. M. Buhr, "Effect of lipoproteins and luteinizing hormone on progesterone production by large and small luteal cells 
throughout the porcine estrous cycle," Journal of animal science, vol. 65 , no. 4, pp. 1027-1033, 1987.

[34] R. E. Ciereszko, B. K. Petroff, A. C. Ottobre, Z. Guan, B. T. Stokes, and J. S. Ottobre, "Assessment of the mechanism by which prolactin stimulates progesterone production by early corpora lutea of pigs," Journal of Endocrinology, vol. 159, no. 2, pp. 201-209, 1998.

[35] J. Hotchkiss, L. E. Atkinson, and E. Knobil, "Time course of serum estrogen and luteinizing hormone (LH) concentrations during the menstrual cycle of the rhesus monkey," Endocrinology, vol. 89, no. 1, pp. 177-183, 1971.

[36] G. Kotwica, "Progesterone level in the peripheral blood and the cytosol progesterone receptor in the uterine mucosa and myometrium of sows during the estrous cycle," Polskie Archiwum Weterynaryjne, vol. 25, no. 1, pp. 77-89, 1986.

[37] I. Dziadkowiec, U. Danilczyk, and R. Rembiesa, "Biosynthesis of progesterone in the rat placenta," Endokrynologia Polska, vol. 33, no. 4-6, pp. 201-207, 1982.

[38] J. Kotwica and G. L. Williams, "Relationship of plasma testosterone concentrations to pituitary-ovarian hormone secretion during the bovine estrous cycle and the effects of testosterone propionate administered during luteal regression," Biology of Reproduction, vol. 27, no. 4, pp. 790-801, 1982.

[39] R. Ciereszko, M. Opałka, B. Kamińska, M. Wojtczak, S. Okrasa, and L. Dusza, "Luteotrophic action of prolactin during the early luteal phase in pigs: the involvement of protein kinases and phosphatases," Reproductive biology, vol. 1, no. 2, pp. 62-83, 2001.

[40] B. Szafranska, A. Ziecik, and S. Okrasa, "Primary antisera against selected steroids or proteins and secondary antisera against $\gamma$-globulins - as available tool for studies of reproductive processes," Reproductive Biology, vol. 2, pp. 187-203, 2002.

[41] A. Singh and A. Krishna, "Localization of adiponectin and its receptor and its possible roles in the ovary of a vespertilionid bat, Scotophilus heathi," General and Comparative Endocrinology, vol. 176, no. 2, pp. 240-251, 2012.

[42] H. H. Ortega, F. Rey, M. M. L. Velazquez, and V. Padmanabhan, "Developmental programming: Effect of prenatal steroid excess on intraovarian components of insulin signaling pathway and related proteins in sheep," Biology of Reproduction, vol. 82, no. 6, pp. 1065-1075, 2010.

[43] G. Gutman, V. Barak, S. Maslovitz, A. Amit, J. B. Lessing, and E. Geva, "Recombinant luteinizing hormone induces increased production of ovarian follicular adiponectin in vivo: implications for enhanced insulin sensitivity," Fertility and Sterility, vol. 91, no. 5, pp. 1837-1841, 2009.

[44] D. V. Lagaly, P. Y. Aad, J. A. Grado-Ahuir, L. B. Hulsey, and L. J. Spicer, "Role of adiponectin in regulating ovarian theca and granulosa cell function," Molecular and Cellular Endocrinology, vol. 284, no. 1-2, pp. 38-45, 2008.

[45] P. Pierre, P. Froment, D. Ngre et al., "Role of adiponectin receptors, AdipoR1 and AdipoR2, in the steroidogenesis of the human granulosa tumor cell line, KGN," Human Reproduction, vol. 24, no. 11, pp. 2890-2901, 2009.

[46] S. Ledoux, D. B. Campos, F. L. Lopes, M. Dobias-Goff, M.-F. Palin, and B. D. Murphy, "Adiponectin induces periovulatory changes in ovarian follicular cells," Endocrinology, vol. 147, no. 11, pp. 5178-5186, 2006.

[47] A. Singh and A. Krishna, "Effects of adiponectin on ovarian folliculogenesis and steroidogenesis in the vespertilionid bat, Scotophilus heathi," General and Comparative Endocrinology, vol. 178, no. 3, pp. 502-510, 2012.
[48] J. E. Caminos, R. Nogueiras, F. Gaytán et al., "Novel expression and direct effects of adiponectin in the rat testis," Endocrinology, vol. 149, no. 7, pp. 3390-3402, 2008.

[49] L. Paschke, T. Zemleduch, M. Rucinski, A. Ziolkowska, M. Szyszka, and L. K. Malendowicz, "Adiponectin and adiponectin receptor system in the rat adrenal gland: Ontogenetic and physiologic regulation, and its involvement in regulating adrenocortical growth and steroidogenesis," Peptides, vol. 31, no. 9, pp. 1715-1724, 2010.

[50] M. Ramanjaneya, A. C. Conner, J. E. P. Brown et al., "Adiponectin (15-36) stimulates steroidogenic acute regulatory (StAR) protein expression and cortisol production in human adrenocortical cells: Role of AMPK and MAPK kinase pathways," Biochimica et Biophysica Acta-Molecular Cell Research, vol. 1813, no. 5, pp. 802-809, 2011.

[51] J.-P. Wen, W.-S. Lv, J. Yang et al., "Globular adiponectin inhibits GnRH secretion from GT1-7 hypothalamic GnRH neurons by induction of hyperpolarization of membrane potential," Biochemical and Biophysical Research Communications, vol. 371, no. 4, pp. 756-761, 2008.

[52] X.-B. Cheng, J.-P. Wen, J. Yang, Y. Yang, G. Ning, and X.Y. Li, "GnRH secretion is inhibited by adiponectin through activation of AMP-activated protein kinase and extracellular signal-regulated kinase," Endocrine, vol. 39, no. 1, pp. 6-12, 2011.

[53] F. Rodriguez-Pacheco, A. J. Martinez-Fuentes, S. Tovar et al., "Regulation of pituitary cell function by adiponectin," Endocrinology, vol. 148, no. 1, pp. 401-410, 2007.

[54] M. Lu, Q. Tang, J. M. Olefsky, P. L. Mellon, and N. J. G. Webster, "Adiponectin activates adenosine monophosphateactivated protein kinase and decreases luteinizing hormone secretion in L $\beta$ T2 gonadotropes," Molecular Endocrinology, vol. 22, no. 3, pp. 760-771, 2008. 


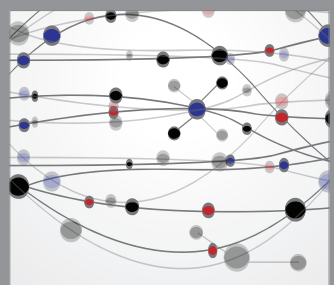

The Scientific World Journal
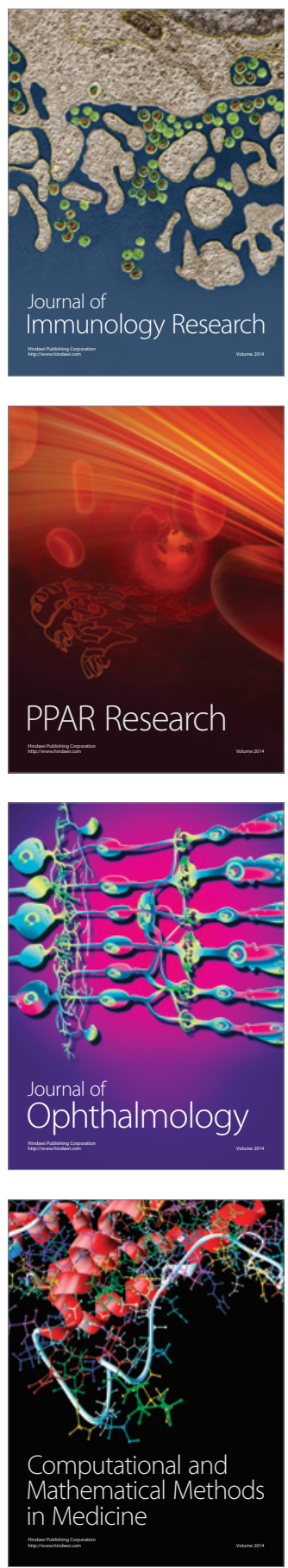

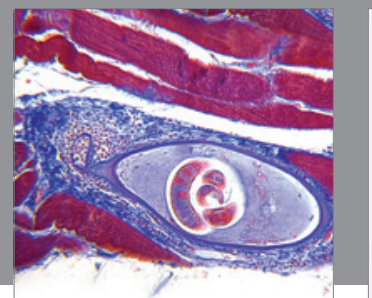

Gastroenterology

Research and Practice
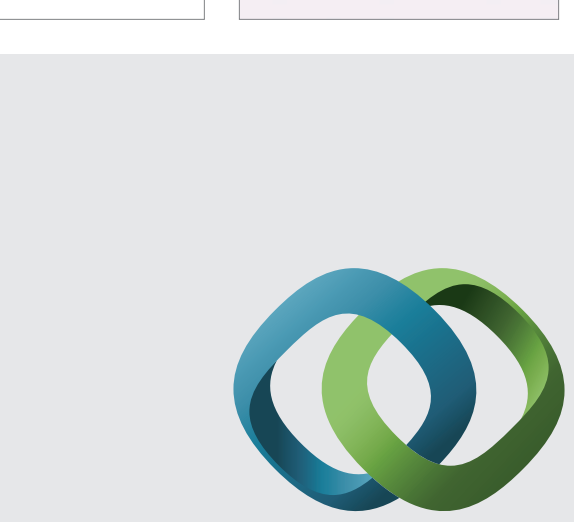

\section{Hindawi}

Submit your manuscripts at

http://www.hindawi.com
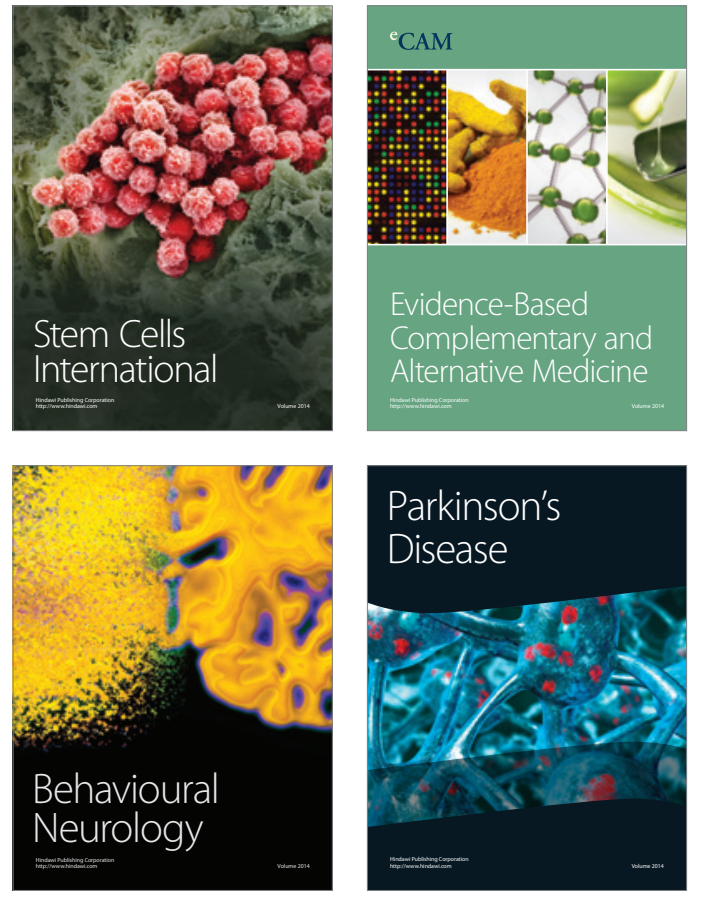
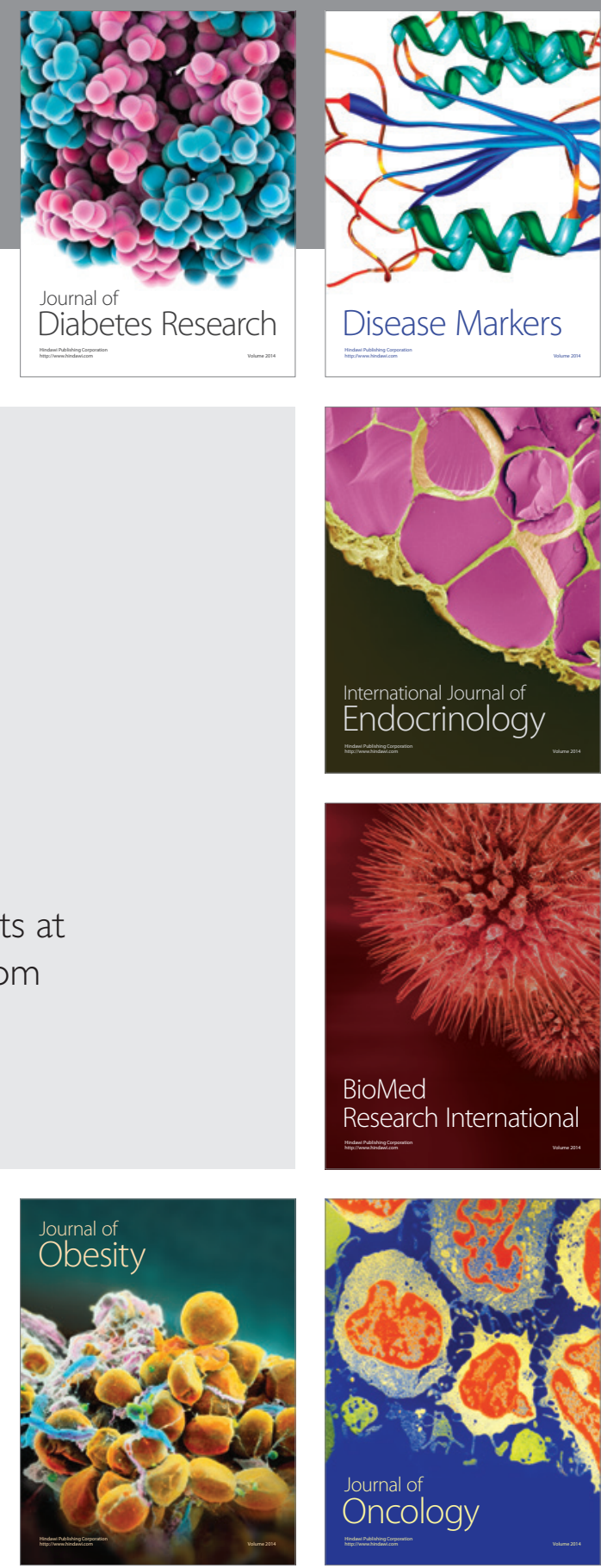

Disease Markers
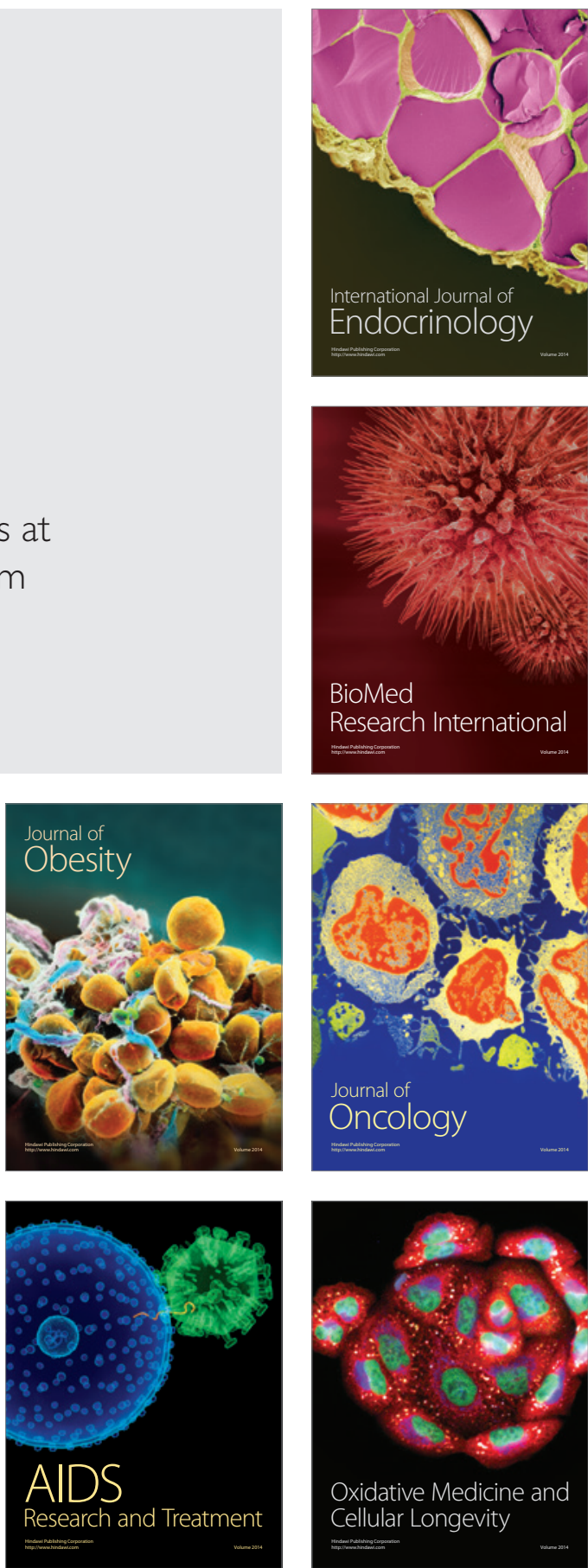